\title{
NÓS, O POVO: AS REDES DAS CASAS DO POVO NOS ALINHAMENTOS CORPORATIVOS (1933-1974)
}

\author{
WE, THE PEOPLE: THE NETWORKS OF CASAS DO POVO IN \\ CORPORATE ALIGNMENTS (1933-1974)
}

DOI: http//dx.doi.org/10.15448/2178-3748.2016.2. 24558

Natália Maria Magalhães Pereira

Lab2PT, Instituto de Ciências Sociais, Universidade do Minho nataliamm.pereeira@ hotmail.com

\begin{abstract}
Resumo: A ênfase da investigação na produção discursiva nos planos ideológico, jurídico e propagandístico (e também em matéria económica) faz denotar o laconismo das pesquisas acerca do impacto dos organismos primários no mundo rural (Grémios da Lavoura e Casas do Povo) - na esteira dos trabalhos pioneiros de Manuel Lucena e de estudos recentes (Estevão, Freire, Garrido). Este artigo pretende explorar as dinâmicas sociais internas das Casas do Povo (1934-1973) e as inter-relações tecidas com os organismos corporativos primários, centrais e regionais (Grémios da Lavoura, Junta Central das Casas do Povo, 1945; Federação Distrital das Casa do Povo de Braga, 1957), através de um estudo intensivo, por amostragem (a rede em estudo é composta por mais de 100 Casas do Povo do Distrito de Braga), tendo como principais fontes os inquéritos às Casas do Povo, um dos mecanismos encontrados pelo Estado para conhecer e acompanhar estes organismos e o mundo rural. Procura-se assim contribuir para a problematização destas entidades enquanto veículos de disseminação política, jurídica e social da estrutura pretensamente massiva do corporativismo.
\end{abstract}

Palavras-chave: Estado Novo; Corporativismo; Casas do Povo;

\begin{abstract}
Research emphasis on discursive production on ideological, legal and propagandistic plans (also in economic matters) denotes the brevity of the research on the impact of primary organisms in rural world (Grémios da Lavoura and Casas do Povo) - in the wake of the pioneering works of Manuel Lucena and recent studies (Estêvão, Freire, Garrido). This article intends to explore the internal social dynamics of Casas do Povo (1934-1973) and the inter-relations woven with central and regional corporate organisms (Grémios da Lavoura, Junta Central das Casas do Povo, 1945; Federação Distrital das Casas do Povo de Braga, 1957), through an intensive study sample (the network under study consists of more than 100 Casas do Povo in Braga's district), having as main sources the surveys to Casas do Povo, one of the mechanisms found by the State to meet and keep up with these bodies and the rural world. This way, we aim to contribute to the questioning of these entities as vehicles of political, legal and social dissemination to the supposedly massive structure of corporatism.
\end{abstract}

Keywords: Estado Novo; Corporatism; Casas do Povo

Em setembro de 1933 é aprovada a Constituição que servirá de base ao Estado Novo que impõe um modelo de república unitária, corporativa e autoritária. O corporativismo, enquanto ideologia e sistema de práticas, atuou como uma forma de disciplina do capital e do 
trabalho, subordinando os interesses económicos aos interesses nacionais, convertendo-o num importante instrumento de controlo e regulação do Estado sobre a sociedade.

As Casas do Povo foram dos primeiros organismos corporativos primários a serem criados, em setembro de $1933^{1}$, no quadro da promulgação dos diplomas fundadores do sistema corporativo português ${ }^{2}$. De relevar a influência do corporativismo italiano como é sublinhado pela historiografia da especialidade, nomeadamente por Manuel Lucena (LUCENA a), 1976). Foram concebidas como organismos de cooperação social com personalidade jurídica, constituindo as únicas instituições criadas de raiz, à semelhança das casas dos pescadores (GARRIDO, 2012), pelo Estado Novo português, sem qualquer paralelo, nos casos italiano e espanhol, pois eram organismos interclassistas que reuniam trabalhadores e proprietários rurais (GAGLIARDI, 2010; VILLAVERDE, 2011; FERNÁNDEZ, 2004). De acordo com o diploma fundador, previa-se a implantação de casas do povo em todas as freguesias classificadas como rurais, sob a iniciativa de particulares interessados, de reconhecida idoneidade, das Juntas de Freguesia, ou outra autoridade administrativa cuja jurisdição estivesse submetida a uma freguesia rural. O diploma instituidor das Casas do Povo previa ainda que naquelas freguesias em que não existisse nenhum dos órgãos político-administrativos mencionados, e que se afigurasse urgente tomar medidas de previdência social, a iniciativa podia recair no Estado, pela mão do Subsecretário das Corporações e Previdência Social. Um diploma posterior, datado de 1970, - decreto n. ${ }^{\circ}$ 445/70, de 23 de setembro - veio ampliar a faculdade de propositura à Corporação da Lavoura, Delegações do Instituto Nacional do Trabalho e Previdência e Junta Central das Casas do Povo ${ }^{3}$.

Competia ao Subsecretário de Estado das Corporações e Previdência Social proceder à aprovação dos respetivos estatutos, que definiam, nomeadamente, a área de influência geográfica da Casa do Povo confinada à freguesia, de forma a limitar a existência de apenas

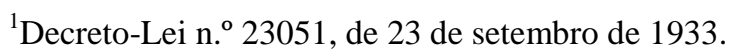

${ }^{2}$ Estatuto Nacional do Trabalho - Decreto-Lei n. ${ }^{\circ}$ 23048; Grémios do Comércio, Indústria e Lavoura - DecretoLei n. ${ }^{\circ}$ 23049; Sindicatos Nacionais - Decreto-Lei n. ${ }^{\circ}$ 23050; Casas do Povo - Decreto-Lei n. ${ }^{\circ}$ 23051; Instituto Nacional do Trabalho e Previdência - Decreto-Lei n. ${ }^{\circ} 23053$ - todos de 23 de setembro de 1933; ficaram para mais tarde as Casas dos Pescadores - Lei n. ${ }^{\circ}$ 1953, de 11 de março de 1937.

${ }^{3}$ Em Espanha, e apesar de haver muitas semelhanças entre a organização corporativa da lavoura e a organização agrária franquista, a formação das Hermandad Sindical de Labradores y Ganaderos parte unicamente por iniciativa da sociedade civil. Estas Hermandad Sindical de Labradores y Ganaderos enquadram todas as pessoas que mantenham algum tipo de relação económica (direta ou indireta) com as atividades agro-pecuárias, tendo as funções coincidentes com as desempenhadas pelos Grémios da Lavoura e Casas do Povo (VILLAVERDE, 2011, p. 282).
} 
um destes organismos aquela área ${ }^{4}$ Em breve, o Decreto-Lei n. ${ }^{\circ} 23618$, de 1 de janeiro de 1934, autorizou a criação de Casas do Povo em localidades, que mesmo não sendo freguesias rurais, reunissem condições e que tornassem recomendável e necessária a sua existência ${ }^{5}$. Em 1938, o Subsecretário de Estado das Corporações e Previdência Social é dotado do poder de aprovar a criação de Casas do Povo abrangendo freguesias limítrofes que, isoladamente não espelhassem condições para a existência destes organismos ${ }^{6}$. Como referimos atrás, formalmente os pedidos para constituição de uma Casa do Povo tinham de partir dos particulares interessados, mas como afirma Dulce Freire, e como aconteceu em outros organismos corporativos, na prática foi o Estado que estimulou ou impôs a sua constituição (FREIRE, 2012, p. 283).

No momento da sua criação, as Casas do Povo eram vocacionadas, idealmente, para o exercício de funções em três áreas de intervenção: previdência e assistência (tendo como objetivo assegurar a proteção e auxílio dos seus sócios em casos de doença, desemprego, inabilidade e velhice); instrução de adultos e crianças; e apoio aos progressos locais, nomeadamente em obras de interesse comum, comunicações, serviço de águas, higiene pública ${ }^{7}$. Cinco anos depois, o Decreto-Lei n. ${ }^{\circ}$ 28859, já referido, acrescenta a estas finalidades, a representação profissional de todos os trabalhadores inscritos como sócios efetivos, bem como o estudo e a defesa dos interesses morais, económicos e sociais dos associados. Importa referir que este último ponto era reservado aos Presidentes das Assembleias Gerais, função que era atribuída exclusivamente aos sócios contribuintes, isto é, proprietários rurais. A estes competia "defender os interesses da Casa do Povo no Grémio da Lavoura de que fizer parte e promover pelos meios ao seu alcance a íntima colaboração entre [os] dois organismos (...) e exercer a representação da Casa do Povo no conselho municipal"8. Deste modo, as negociações dos acordos de trabalho eram realizadas entre proprietários e, à partida, entre iguais. Como afirma Lucena “é de rezar-se a Deus Pai para que [o] Presidente seja um amigo dos pobres, que nem sequer o elegem” (LUCENA a), 1976, p.258).

\footnotetext{
${ }^{4}$ Artigo $2^{\circ}$ e Artigo $3^{\circ}$ do Decreto-Lei n. ${ }^{\circ} 23051$, de 23 de setembro de 1933.

${ }^{5}$ Artigo $1^{\circ}$ do Decreto-Lei n..$^{\circ} 23618$, de 1 de março de 1934 . No caso do Distrito de Braga referimo-nos à Casa do Povo de Póvoa de Lanhoso, que se instala na Sede do Concelho, e não numa freguesia rural, abrangendo algumas freguesias rurais limítrofes.

${ }^{6}$ Artigo $2^{\circ}$ do Decreto-Lei n. ${ }^{\circ} 28859$, de 18 de julho de 1938.

${ }^{7}$ Artigo $4^{\circ}$ do Decreto-Lei n. ${ }^{\circ} 23051$, de 23 de setembro de 1933.

${ }^{8}$ Alíneas c) e d) do Artigo $6^{\circ}$ do Decreto-Lei n. ${ }^{\circ} 28859$, de 18 de julho de 1938.
} 
Dois anos mais tarde, em 1940, através do Decreto-Lei n. ${ }^{\circ}$ 30710, de 29 de agosto, é reforçada a componente relacionada com o apoio aos progressos locais, de forma a contribuir para o combate ao desemprego local, mediante a cooperação em obras de iniciativa e responsabilidade do Estado, autarquias locais ou proprietários, executadas em épocas de carência de trabalho. Desta forma, as Casas do Povo passam a colaborar em tarefas ligadas ao recrutamento de desempregados, à fiscalização das condições de trabalho e à comparticipação do custo de obras, na sequência da autorização das respetivas obras pelo Subsecretariado de Estado das Corporações e Previdência Social. Seguramente, como sublinha Maria Manuel Alves, o Estado visava assegurar o bom uso dos fundos das Casas do Povo em benefício do interesse comum, uma vez que o controlo das Casas do Povo residia nas mãos dos proprietários rurais e daí exigir a aprovação prévia pelo Subsecretário de Estado (ALVES, 1998, p.60). A experiência evidenciou, porém, segundo Manuel Lucena, que a aplicação dos fundos das Casas do Povo aos progressos locais resultou em benefício exclusivo de certos proprietários, para benfeitoria das suas propriedades, de uma forma tão exuberante "ao ponto de causar escândalo" (LUCENA a), 1976, p.253).

Em $1969^{9}$, no quadro da governação marcelista e no âmbito da reorganização do sistema corporativo português, são redefinidas as finalidades destes organismos, regulamentadas em termos de cooperação social e de promoção do desenvolvimento local. Em simultâneo, é alargada a representação profissional aos trabalhadores agrícolas por conta de outrem, bem como a previdência e a assistência aos trabalhadores residentes na respetiva área, mediante o pagamento voluntário de contribuições. As competências das Casas do Povo são assim recentradas nas funções de previdência social, assegurando-se "um esquema especial de prestações" no âmbito das caixas sindicais de previdência e no quadro do regime especial de abono de família" (FREIRE, 2012, p.284). Desse modo, as prestações regulares, provenientes do fundo de previdência das caixas sindicais, são geridas pela Caixa Nacional de Pensões, que assegura a sua atribuição aos trabalhadores rurais e aos pequenos proprietários. Ao mesmo tempo, é estabelecido "um auxílio complementar" aos sócios efetivos e respetivas famílias em "situações de comprovada necessidade", dependente de receitas próprias de cada Casa do Povo ou de eventuais subsídios (FREIRE, 2012, p.284). Através destas disposições, o Estado português procurou contribuir para atenuar as discrepâncias notórias que afastavam Portugal dos sistemas de previdência social construídos na Europa do pós-II Guerra.

${ }^{9}$ Lei n. ${ }^{\circ} 2144,29$ de junho de 1969. 
Além do controlo exercido pelo Estado na criação das Casas do Povo, mediante a aprovação prévia dos respetivos estatutos, como referimos atrás, estes organismos eram ainda sujeitos à fiscalização regular do Instituto Nacional do Trabalho e Previdência (INTP). Com efeito, as delegações distritais do INTP eram responsáveis pelo controlo das dinâmicas internas das Casas do Povo, concretamente através da aprovação das eleições dos órgãos diretivos das respetivas casas, da fiscalização da atividade administrativa e financeira destes organismos, reservando-se ainda o direito de poder suspender temporariamente o exercício das mesmas ou inclusive dissolve-las, na eventualidade de a sua ação se revelar prejudicial aos interesses da ordem pública ${ }^{10}$. Em suma, de acordo com Howard J. Wiarda, a disciplina corporativa obrigava os grupos socioprofissionais a fornecer ao Estado os seus estatutos organizativos, de acordo com a lei, a apresentar os seus membros, os seus corpos gerentes, a informar sobre o que fazem, a proveniência dos seus fundos financeiros e como os gerem (WIARDA, 2012, P. 271).

Nos inícios dos anos 40 são lançados um conjunto de inquéritos à população rural, por diferentes entidades públicas. A iniciativa tem como propósito atualizar o conhecimento das diversas autoridades sobre o mundo rural e ao mesmo tempo avaliar e aperfeiçoar os sistemas de intervenção corporativa no terreno. Os inquéritos versam sobre temáticas diversas, entre as quais se salientam: as bases da alimentação rural, as condições económicas rurais e culturais da população rural, os hábitos e práticas coletivas das respetivas populações (nomeadamente sobre a audição da rádio). Por último, em 1945, por iniciativa da Comissão de Inquérito Parlamentar à Organização Corporativa (ROLLO, 2012) é realizado um inquérito às Casas do Povo com o fim de avaliar o desempenho destes organismos. Neste artigo centraremos a nossa atenção no Inquérito às Casas do Povo, datado de 1947, elaborado pela Junta Central das Casas do Povo, com o intuito de observar como se encontravam estes organismos criados um pouco por todo o país (Fundo das Casas do Povo - Arquivo do Centro Distrital de Braga da Segurança Social).

\footnotetext{
${ }^{10}$ Artigo $27^{\circ}$ do Decreto-Lei n. ${ }^{\circ} 23051$, de 23 de setembro de 1933.
} 


\section{A REDE DAS CASAS DO POVO NO DISTRITO DE BRAGA}

A distribuição das Casas do Povo no distrito de Braga evidencia uma elevada densidade, à escala nacional, parcialmente explicada pela correspondente densidade populacional do distrito. É neste distrito que o movimento relativo à criação e implementação de Casas do Povo se revela mais acelerado e progressivo, já que em 1945 se contabilizam quase uma centena ${ }^{11}$. Em todo o caso, só uma análise mais detalhada, centrada, nomeadamente, na caracterização social dos órgãos diretivos (concretamente da Assembleia Geral) permitirá esclarecer adequadamente as razões da recetividade a este organismo, numa região do País, que à partida não espelhava problemas de conflitualidade social, como acontecia com alguns dos distritos do sul.

Mapa I - Distribuição dos organismos corporativos primários no distrito de Braga (1933-1974): casas do povo, grémios do comércio, da lavoura e da indústria, sindicatos

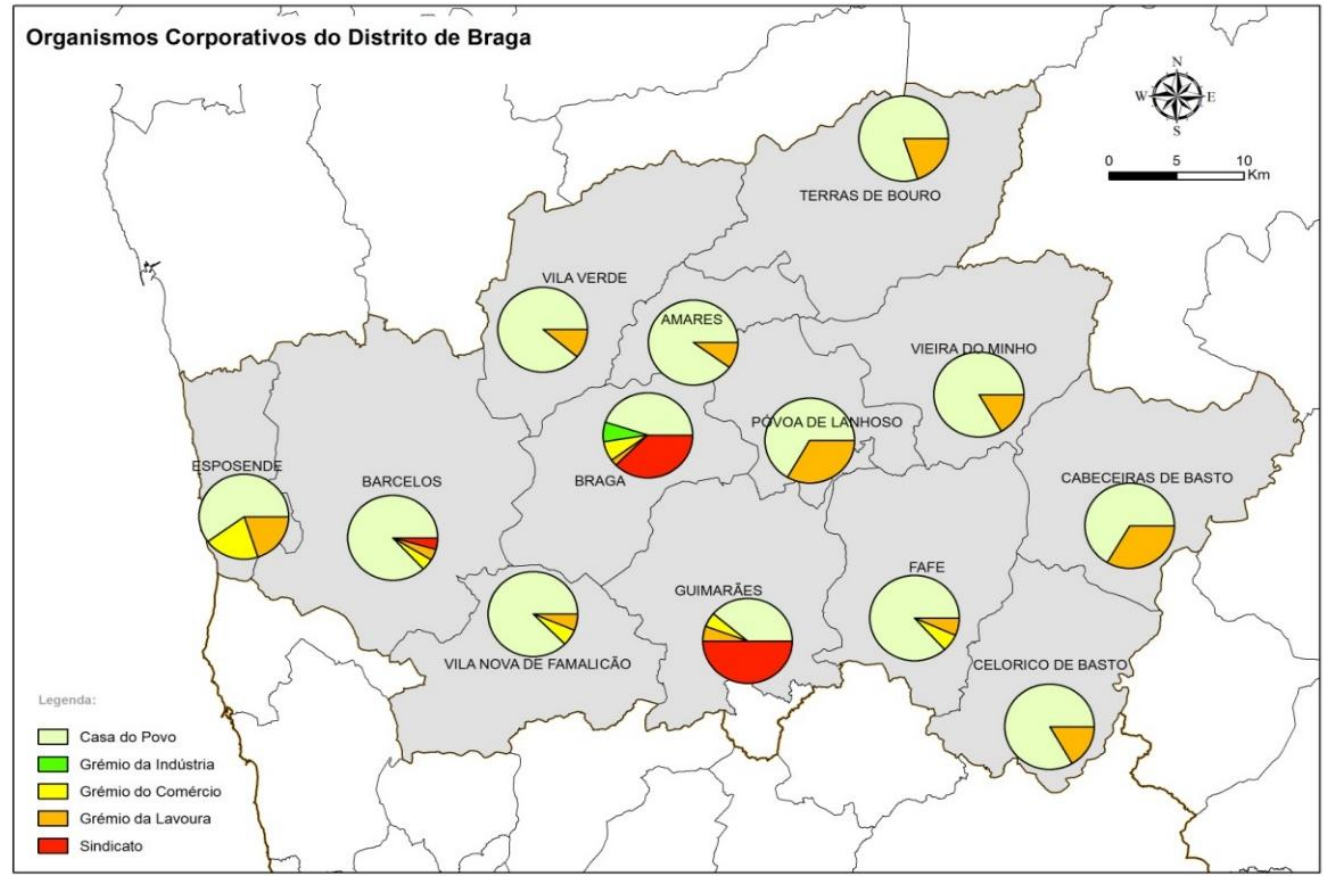

Fonte: Informação obtida a partir do Boletim do Instituto Nacional do Trabalho e Previdência (19331974).

\footnotetext{
${ }^{11}$ Para uma perspetiva nacional relativa à distribuição das Casas do Povo no continente ver: LUCENA, Manuel de. A evolução do sistema corporativo português. Vol. I. O Salazarismo. Lisboa: Perspectivas \& Realidades, 1976; FREIRE, Dulce. O Estado Corporativo em acção: sociedade rural e construção da rede de Casas do Povo. In: ROSAS, Fernando; GARRIDO, Álvaro (Coord.). Corporativismo, Fascismos, Estado Novo. Coimbra: Edições Almedina, 2012.
} 
A análise sobre a malha de organismos corporativos à escala do distrito de Braga evidencia um claro predomínio dos organismos ligados ao mundo rural - Casas do Povo e Grémios da Lavoura - presentes em todos os concelhos do distrito, seguidos com distância considerável, pelos Grémios do Comércio (TORRES, 2013, p. 23) e pelos Sindicatos (cfr. Mapa I). Os organismos corporativos do comércio distribuem-se pelos concelhos do distrito: Braga, Fafe (grémios pluriconcelhios), Barcelos, Esposende, Guimarães, e Vila Nova de Famalicão (grémios concelhios). Os demais organismos corporativos apresentam uma representação residual. É o caso dos Sindicatos, em número de 21, sedeados nos concelhos de Braga, Guimarães, e Barcelos, em razão das características do tecido industrial da região, assente em estruturas dominantemente artesanais e tradicionais. No que toca aos Grémios da Indústria registam-se apenas dois casos, com sede na cidade de Braga, sinal inequívoco da fraca representação dos industriais, á semelhança, aliás, das demais regiões de província de então.

Mapa II - Fundação das Casas do Povo por década no distrito de Braga (1933-1974)

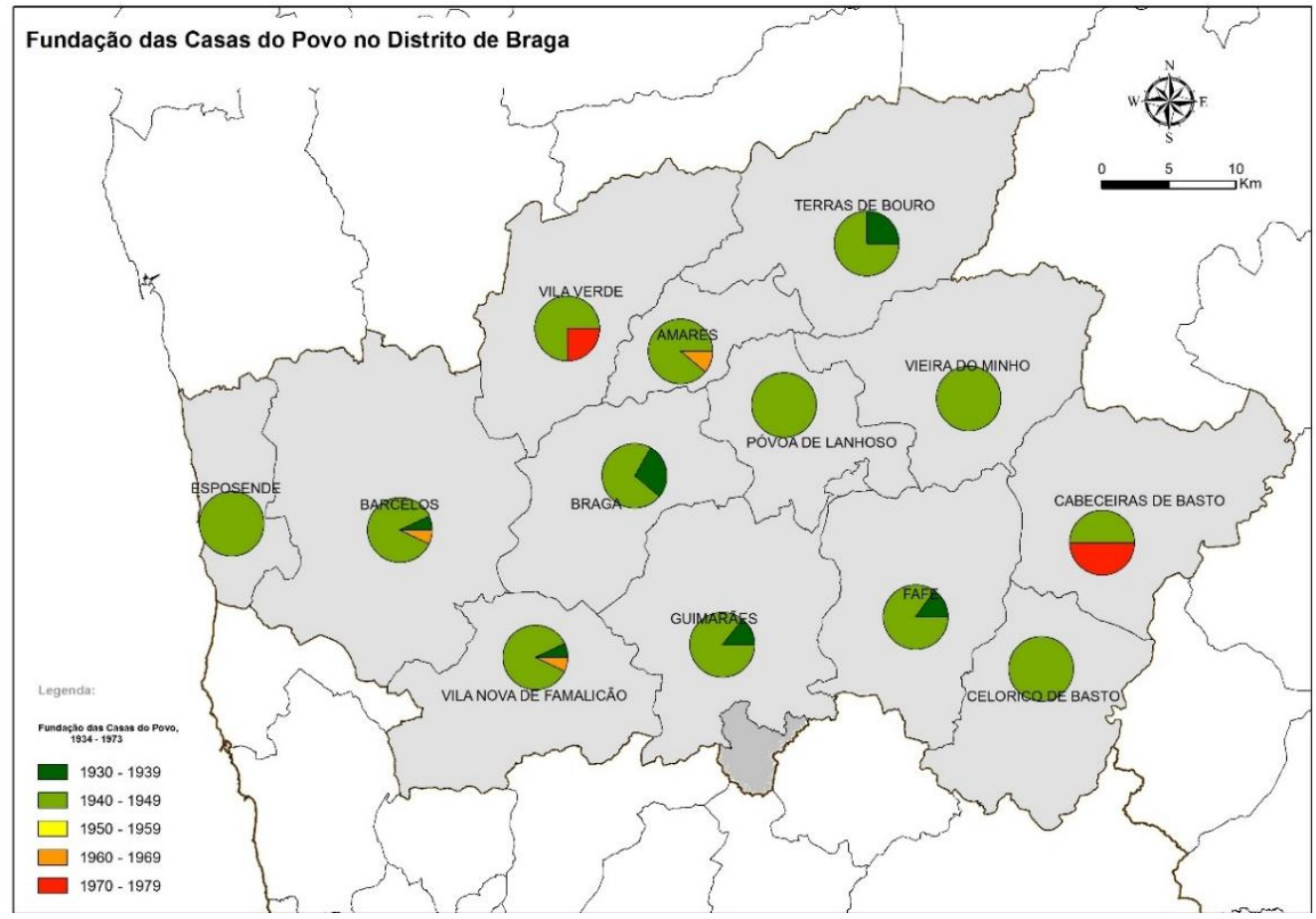

Fonte: Informação obtida a partir do Boletim do Instituto Nacional do Trabalho e Previdência (19331974) e da consulta conjunta do Fundo das Casas do Povo - Arquivo do Centro Distrital de Braga da Segurança Social 
A importância do estudo da rede corporativa rural explica-se não só pela sua elevada densidade, mas sobretudo pela sua elevada concentração nas décadas de institucionalização e afirmação do Estado Novo, em especial nos anos 40, que registam entre 1940 e 1945, um total de 90 (cfr. Mapa II). Em contraponto, assinalem-se os valores residuais das casas criadas nos anos 60 e 70, época de crescimento das Casas Rurais à escala metropolitana, em razão dos desenvolvimentos associados ao alargamento da previdência social, apontado atrás. A distribuição no distrito (ver Mapa III) demonstra uma maior intensidade nos concelhos de Barcelos, Braga, Vila Nova de Famalicão e Fafe. Em contraste, os concelhos de Cabeceiras de Basto, Póvoa de Lanhoso e Esposende apresentam os números mais reduzidos do distrito. As razões para esta discrepância não são ainda, no estado atual da investigação, passiveis de serem explicadas, uma vez que nem a dimensão geográfica dos concelhos, nem a respetiva densidade populacional parecem constituir fatores decisivos para a implantação de Casas do Povo.

Mapa III - Distribuições das Casas do Povo do distrito de Braga por concelhos (19331974)

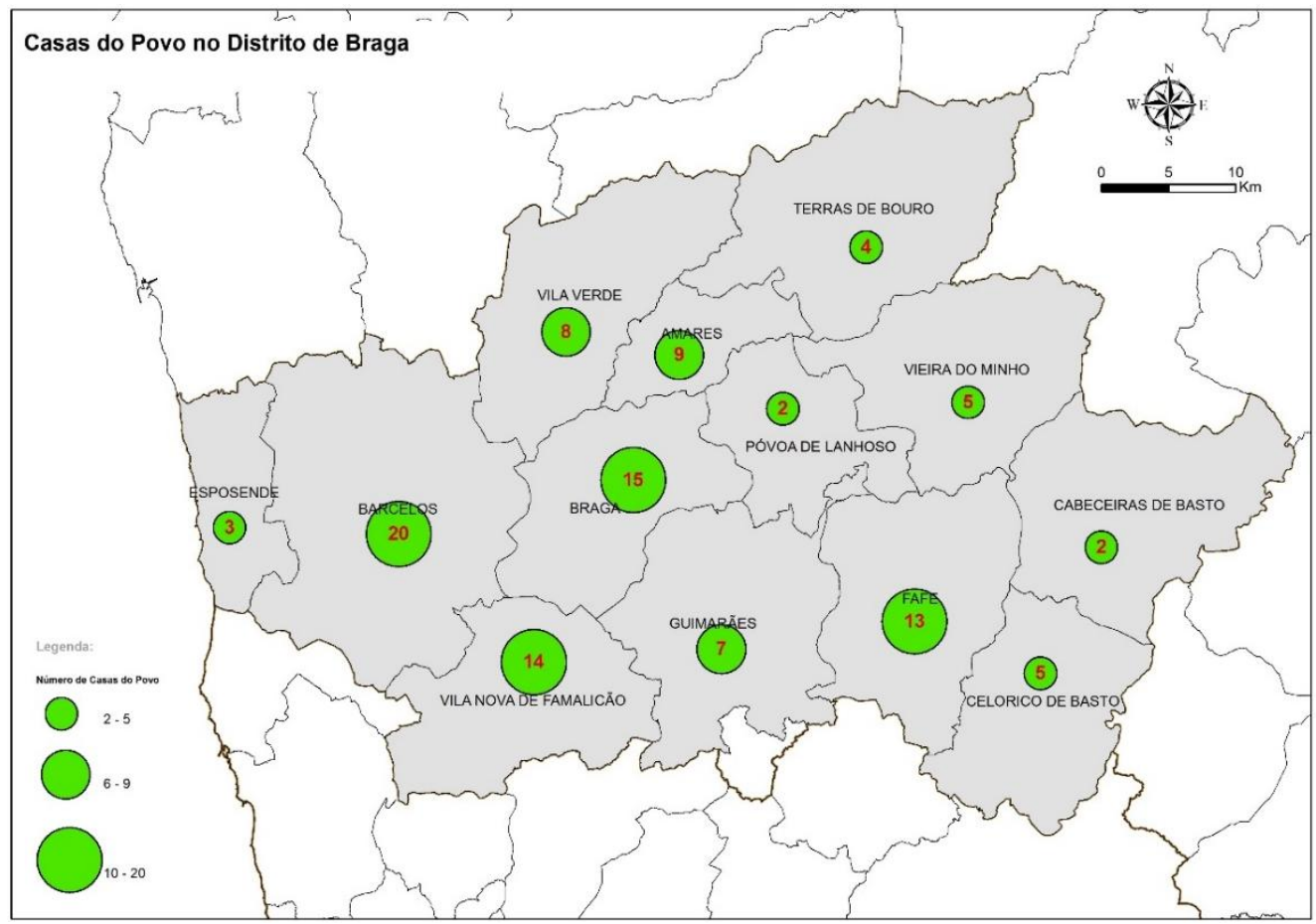

Fonte: Informação obtida a partir do Boletim do Instituto Nacional do Trabalho e Previdência (19331974) e da consulta conjunta do Fundo das Casas do Povo - Arquivo do Centro Distrital de Braga da Segurança Social 
Na documentação compulsada no Arquivo do Centro Distrital de Braga da Segurança Social, que aloja núcleos documentais significativos dos arquivos históricos das Casas do Povo $^{12}$, constatamos a continuidade ininterrupta das casas criadas, na maioria dos casos até aos anos 80-90 do século XX. Igualmente, podemos verificar a excecionalidade dos casos de suspensão temporária, fusão e/ou de extinção previstos na legislação ${ }^{13}$. Registe-se ainda que, maioritariamente, as Casas do Povo seguem as prescrições legislativas, mormente no plano da reestruturação estatuária, figurando ainda, com expressão substantiva, a atividade inspetiva que atesta a operacionalidade dos órgãos de vigilância e controlo sobre o espaço rural.

\section{AS CASAS DO POVO E O UNIVERSO DOS SÓCIOS}

A criação das Casas do Povo encontra-se, à partida, dependente da proposta de uma comissão organizadora, responsável pela gestão do organismo nos dois primeiros anos, composta por cinco proprietários agrícolas (categoria alargada aos produtores agrícolas) e cinco trabalhadores agrícolas, na condição, respetivamente, de sócios protetores ${ }^{14}$ e sócios efetivos. Como afirma Manuel Lucena, está aqui o ponto que marca este organismo, ao contrário do que acontece nos sindicatos e nos grémios, as Casas do Povo juntam trabalhadores e patronato. No fundo, os trabalhadores rurais não têm instituições mesmo suas, pois também os proprietários podem inscrever-se, e aliás são eles quem as dirigem (LUCENA a), 1976, p.247). São sócios efetivos os chefes de família e outros indivíduos do sexo masculino com mais de 18 anos, no gozo dos seus direitos civis e políticos; os proprietários rurais sem bens suficientes para se diferenciarem dos trabalhadores rurais; as mulheres que não chefes de família; e os menores de 18 anos, de forma a garantir o usufruto dos benefícios (estando excluídos todos os estrangeiros e portugueses a residir no estrangeiro), para além da

\footnotetext{
${ }^{12}$ Núcleos documentais: Administração; Contabilidade; Estatutos/Alvavrá; Quotas; Corpos Gerentes; Acordos; Sede; Atividade Cultural; Correspondência; Funcionários; Fundo Comum; Inspeções; Inquéritos; Previdência e Assistência; Inventários.

${ }^{13}$ Como exemplo: a Casa do Povo de Póvoa de Lanhoso, suspensa durante um ano, de 1945 a 1946; as fusões das Casas do Povo de Lago e Rendufe, formando uma nova Casa do Povo, Entre Homem e Cávado, e a inatividade da Casa do Povo de Frades, inativa desde o ano de 1951, vindo a ser absorvida pela Casa do Povo de Póvoa de Lanhoso.

${ }^{14}$ Entre os produtores agrícolas são considerados as entidades singulares ou coletivas, proprietários ou que explorem (como rendeiros, meeiros, parceiros ou administradores) prédios rústicos e as mais entidades assim consideradas pela legislação reguladora dos organismos corporativos ou de coordenação económica).
} 
redefinição das categorias operadas nos anos 60 e 70. Em rigor, note-se que as categorias dos sócios são alteradas pelo Decreto-Lei n. ${ }^{0}$ 30710, de 29 de agosto de 1940, nas suas denominações e também nos critérios de acesso. Assim, os sócios efetivos passam a ser: os trabalhadores rurais, do sexo masculino, ou outros que deles não se diferenciem do ponto de vista material ou referente ao modo de vida, residentes na área da Casa do Povo, desde que sejam chefes de família ou maiores de 18 anos; e os produtores agrícolas que não possam ser contribuintes pelo facto de os seus bens ou rendimentos não serem suficientes para assegurar essa condição. Os sócios protetores são agora designados de contribuintes. A categoria de protetores abrange todas as entidades que contribuam voluntária e periodicamente com quaisquer quantias para as receitas do organismo. Surgem ainda os benfeitores, pessoas que por prestarem serviços ou auxiliarem com donativos consideráveis sejam merecedoras dessa distinção.

A Lei n. ${ }^{\circ}$ 2144, de 29 de junho de 1969 traz mais alterações às categorias dos associados: os sócios efetivos passam a abranger trabalhadores por conta d'outrem na agricultura, silvicultura e pecuária, e deixa de limitar o acesso a esta categoria apenas ao sexo masculino. Introduz ainda que todos os associados passam a ter acesso à Assembleia Geral, de pleno direito, podendo "participar nas eleições dos órgãos das Casas do Povo e na apreciação dos assuntos relacionados com as funções de cooperação social” (LUCENA b), 1976, p.83). Protetores e benfeitores são alargados a pessoas e entidades, respetivamente. Em 1973, o Decreto n. ${ }^{\circ}$ 249/73, de 17 de maio, considera produtores agrícolas, todas as entidades singulares ou coletivas de direito público ou privado, proprietários de prédios rústicos, ou que os explorem mediante contrato de arrendamento; são também considerados proprietários os usufrutuários, os meros possuidores e os administradores na ausência dos proprietários. $\mathrm{O}$ estatuto de sócio relaciona-se diretamente com as funções diretivas previstas no plano da gestão interna da Casa do Povo.

\section{GESTÃO INTERNA DAS CASAS DO POVO E AS INTERRELAÇÕES COM O GRÉMIO DA LAVOURA}

A gestão interna do organismo era confiada a dois órgãos: assembleia geral e direção. A assembleia geral é composta por um Presidente (eleito entre contribuintes) e dois vogais 
(um efetivo e um contribuinte). A direção, por seu turno, é constituída por Presidente, Tesoureiro e Secretário (eleitos entre efetivos), o que atesta o papel central dos trabalhadores agrícolas na gestão do organismo. As alterações mais significativas têm lugar por diploma de 1969 que abre os cargos da direção, com a exceção da vice-presidência, a todos os associados independentemente do estatuto de sócio ${ }^{15}$.

Os cargos sociais são desempenhados no quadro de mandatos de três anos e de forma gratuita. A direção reúne ordinariamente, pelo menos, uma vez por mês, e sempre que julgado necessário para o funcionamento do organismo. A assembleia geral por sua vez reúne, ordinariamente, uma vez por ano (eleição da mesa e nova direção), admitindo-se a reunião extraordinária, na condição de ser convocada pelo presidente ou a pedido de $1 / 3$ dos sócios efetivos que a integram ${ }^{16}$. Persiste por esclarecer a capacidade dos agentes diretivos cumprirem os fins que se encontram adstritos a estes organismos, problemática que só no quadro de uma investigação mais ampla poderá ser cabalmente respondida, atendendo ao número residual de estudos sobre o objeto em análise. Seja como for, a dinamização da orgânica das Casas do Povo encontra-se dependente e condicionada pela capacidade de angariar fundos de forma a garantir a viabilidade económica e a operacionalização das atividades projetadas. Daí a importância do pagamento das quotas pelos associados, bem como dos valores fixados, de acordo com a trajetória legislativa que sugere o agravamento significativo das quotizações.

O montante de valores fixado em 1933 situa-se em 1\$00 para os sócios efetivos e 5\$00, limite mínimo para os sócios contribuintes. Sete anos mais tarde, por diploma de 1940, são alterados os valores das quotas, que oscilam entre $1 \$ 50$ e os $3 \$ 00$, de acordo com a decisão anual da Direção, em função dos benefícios que se propunha atingir. Analogamente as quotas dos contribuintes são revistas e fixadas segundo os rendimentos dos produtores agrícolas, em classes. Mais tarde, tem lugar um reajustamento das quotas dos produtores agrícolas de forma a compatibilizarem-se com os montantes canalizados para os Grémios de Lavoura, facto que origina negociações ${ }^{17}$ com vista ao acordo de quotas, entre outras alterações observadas por diploma de $1970^{18}$.

\footnotetext{
${ }^{15}$ A composição da direção sofre alterações com a Lei n. ${ }^{\circ} 2144$ de 29 de junho de 1969, acrescentando os cargos de Vice-Presidente (eleito na assembleia geral entre os efetivos trabalhadores agrícolas por conta d'outrem) e de três vogais (eleitos na assembleia geral entre os sócios da Casa do Povo em pleno gozo dos seus direitos); a Direção designa um dos vogais para tesoureiro e outro para secretário.

${ }^{16}$ Com a Lei n. ${ }^{\circ} 2144$ a assembleia geral passa a ter sessões nos meses de Março e Dezembro, para apreciação e votação do relatório e contas do ano anterior e do orçamento do ano seguinte.

${ }^{17} \mathrm{~A}$ necessidade de haver negociação entre as partes, advém do facto do grémio procurar defender os interesses dos produtores agrícolas tentando conseguir-lhes uma quota mais baixa. Em sentido contrário caminha a Casa do
} 
Só no ano de 1937 se estabelecem as bases da organização corporativa da agricultura com a Lei n. ${ }^{\circ}$ 1957, de 20 de Maio. Daí a importância do estudo articulado das Casas do Povo com os Grémios da Lavoura, organismo que representa todos os produtores agrícolas da respetiva área (obrigatoriamente inscritos como sócios - artigo $8^{\circ}$. do capítulo II), no que toca à representação dos seus interesses perante o Estado, os demais organismos corporativos e organismos de coordenação económica. As negociações sobre os acordos constituem um espaço de interação privilegiado com as demais estruturas corporativas. O estudo exaustivo da correspondência permitirá atestar os organismos intervenientes - designadamente o Delegado do Instituto Nacional do Trabalho e Previdência. Importa, por outro lado, aprofundar o estudo das interações entre estes organismos no que respeita à circulação de informação, designadamente no quadro da participação dos corpos gerentes das Casas do Povo nas reuniões dos Grémios da Lavoura (eleitos de entre os presidentes das assembleias gerais das Casas do Povo) e da colaboração em iniciativas conjuntas com vista à elevação das condições sociais e morais da população agrícola.

\section{OS INQUÉRITOS ÀS CASAS DO POVO}

Os inquéritos dirigidos às condições de vida da população rural constituem um outro indicador sobre o interesse no alargamento do conhecimento sobre o mundo rural. A realização destes inquéritos permitia ao Estado recolher informações relevantes sobre a vivência na ruralidade e as dinâmicas sociais internas das Casas do Povo, constituindo, paralelamente, um meio de acompanhamento e supervisão destas realidades. O tratamento

\footnotetext{
Povo, que procura definir quotas mais elevadas por forma a aumentar as suas receitas. Os acordos de quotas divididos em 12 cláusulas apresentam aos respetivos associados o valor das quotas acordado por ambas as partes, traçavam uma classificação por categorias dos sócios contribuintes de acordo com os seus rendimentos, sendo anexado ao mesmo uma listagem com os rendimentos coletáveis rústicos de todos os sócios contribuintes da Casa do Povo e a sua respetiva quota.

${ }^{18}$ Os montantes definidos não são inferiores a $5 \$ 00$, resultando do acordo entre a Casa do Povo e o Grémio da Lavoura do concelho. Com a Lei $\mathrm{n}^{\circ} .2144,29$ de junho de 1969, os sócios protetores ficam abrangidos pelo regime de quotização, fixando a Assembleia Geral, sob proposta da Direção, as quotas mínimas. Em 1970, com o Decreto n. ${ }^{\circ} 445 / 70$, de 23 de setembro, são introduzidas alterações ao sistema de quotização: nos sócios efetivos a quota é fixada nos $20 \$ 00$ para os homens e $12 \$ 50$ para as mulheres. A quota mínima dos contribuintes é estipulada de acordo com o rendimento coletável dos prédios que constituem as respetivas explorações agrícolas, entre 2 ou 3 por mil, arredondadas ao escudo imediatamente superior, não sendo inferiores a $5 \$ 00$. A quotização dos sócios protetores é fixada no mínimo de $7 \$ 50$.
} 
destas fontes assume particular importância pela visão de conjunto que disponibiliza, possibilitando o acesso a informação produzida pelos intervenientes diretos.

Entre os inquéritos recenseados, assinalem-se os inquéritos de 1941, o primeiro centrado na alimentação dos trabalhadores agrícolas (Luís Quartin Graça), e o segundo, datado de novembro, sobre as condições económicas, sociais e culturais da população agrícola e respetivas aspirações de classe (também aplicado nos Grémios da Lavoura). No inquérito lançado no ano seguinte, em 1942, são analisadas as práticas de audição de rádio (horário mais adequado para a audição da Rádio Nacional, número de aparelhos existentes na freguesia, entre outras). Em 1945, um outro inquérito questionava a existência de iluminação elétrica aos domingos, entre outras questões.

Só em fevereiro 1945 se constituiu na Assembleia uma comissão de inquérito ao sistema corporativo com o objetivo de avaliar os seus resultados e as possíveis soluções para a consumação do Estado Corporativo. O relatório geral só é apresentado em 1947, e expressa a não correspondência, de um modo geral, das Casas do Povo aos preceitos com que foram idealizadas.

No ano em que se apresenta o relatório, é feito um inquérito às Casas do Povo de todo o país, com a coordenação da Junta Central das Casas do Povo. Criada pelo Decreto-Lei n. ${ }^{\circ}$ 34373, de 1 de janeiro de 1945, este organismo tem como primeira finalidade orientar e coordenar a ação das Casas do Povo, entre outras competências que versam sob a orientação dos fundos e gestão das mesmas, e ao mesmo tempo na promoção da vida cultural.

Possivelmente, este inquérito surge na sequência da criação desta Junta Central, para que de alguma forma, ainda que não constitua elemento fundamental de verificação do cumprimento dos preceitos dos Estatutos, permita observar, por um lado, até que ponto estas Casas do Povo estariam a corresponder ao estipulado por Lei, e ao mesmo tempo verificar que mudanças seriam pertinentes para a boa gestão destes organismos. Talvez este último ponto seja o objetivo chave deste inquérito, uma vez que para controlo do cumprimento da legislação havia as inspeções (FERREIRA; PEREIRA, 2016).

Na capa do inquérito de 1947 são pedidas as referências da Casa do Povo designação, informações sobre a sede (lugar, freguesia, concelho, distrito) e data de alvará encontrando-se este dividido em 14 capítulos: âmbito, receitas, bens, sede e mobiliário, simbologia, pessoal, ambiente, ação social, previdência e assistência, ação cultural, fomento local, diversões, legislação e informações complementares. 
O inquérito cobre diversas questões da organização interna destes organismos corporativos, questionando os seus fins - observados nos respetivos Estatutos e legislação - o cumprimento dos mesmos e a gestão interna dos organismos (a nível económico, moral, educativo e social). Na mesma medida questiona as condições da sua sede, a pertinência da sua existência, a qualidade dos seus espaços, as medidas que vão sendo tomadas para um melhoramento da instrução dos seus associados, a promoção da cultura, e do aproveitamento dos tempos livres.

A seleção dos inquéritos utilizados neste artigo partiu da necessidade de representar todos os concelhos do distrito. Nesse sentido, foram selecionadas, quando possível, duas Casas do Povo por concelho, instituídas em ambientes distintos, isto é, o mais próximo e o mais afastado possível da sede de concelho ${ }^{19}$.

Dos 14 capítulos enunciados, o "âmbito" e "receitas" são os mais respondidos, em contraponto com os "ação cultural", "fomento local", e "diversões", demonstrando a escassez de atividades correspondentes a estes pontos. As Casas do Povo de Rego e Seide, situadas nos concelhos de Celorico de Basto e Vila Nova de Famalicão, respetivamente, são as que respondem com mais detalhe às questões colocadas, sendo especialmente opinativas quando são requeridas sugestões ou apreciações. É curioso observar que quem responde a estes inquéritos, em ambos os casos, são proprietários - um comerciante e um industrial Presidentes da Assembleia Geral (Sócios contribuintes). Já as respostas mais sintéticas são redigidas pelos escriturários, e Presidentes de Direção, que apresentam algumas lacunas, relacionadas com a própria profissão e categoria de associado. É relevante assinalar que este panorama também se reflete nas suas respostas. Quando questionados se um organismo poderia constituir a sua Direção com apenas sócios efetivos (trabalhadores rurais), aqueles que respondem afirmativamente são todos sócios efetivos, e portanto, trabalhadores rurais, já aqueles que rejeitam esta situação são sócios contribuintes. Porém, importa acrescentar que a resposta é afirmativa, se estes tiverem o amparo e a orientação do Presidente da Assembleia Geral. Isto é, um sócio contribuinte para orientar e supervisionar.

A falta de instrução dos trabalhadores rurais, a falta de aptidões indispensáveis - como o saber ler e escrever com relativa facilidade - é a justificação para a rejeição de uma Direção composta inteiramente por sócios efetivos, considerando-os incapazes de uma boa gestão, por

\footnotetext{
${ }^{19}$ Foram selecionadas as Casas do Povo de: Amares, Valo do Cávado, Rendufe, Esposende, Forjães, Arcozelo, Milhazes, Macieira de Rates, Este, Celeirós, Arco de Baúlhe, Celorico de Basto, Rego, Silvares, Travassós, Joane, Seide, Ronfe, Serzedo, Póvoa de Lanhoso, Vieira do Minho, Ribeira do Neiva, Covas e Gerês (Moimenta).
} 
falta de competência, cultura e capacidade para dirigir os destinos da Casa do Povo. Este era o prisma que se desenhava das direções das Casas do Povo, que só com a Lei n. ${ }^{\circ}$ 2144, de 29 de junho de 1969, sofre alterações ao permitir a eleição de sócios contribuintes para Presidentes de Direção. Com isto podia um organismo ser orientado, na totalidade, apenas por sócios contribuintes, gerindo eles próprios uma Casa do Povo que tinha como propósito, preconizado na legislação, o auxílio e proteção dos sócios efetivos, e mais tarde a representação dos trabalhadores rurais.

A questão das quotas é outro ponto em que se observam algumas fragilidades, sendo visto como um problema para o qual se procura uma solução. $\mathrm{Na}$ opinião da maioria a dificuldade de cobrança prende-se com a falta de interesse por parte dos sócios efetivos no cumprimento desse dever. As respostas são notórias: este grupo de sócios encara a Casa do Povo apenas como um espaço de assistência, pagando as suas quotas sempre que necessitam do auxílio da mesma. Importa referir que isto espelha o que se passa com diversas Casas do Povo, não se trata de uma opinião vincada pelos sócios contribuintes (que geralmente respondem a este inquérito). Quando confrontamos estes inquéritos com as inspeções às Casas do Povo é evidente o constrangimento que esta situação representa, prolongando-se até aos anos 50, período em que se reestrutura a assistência e a previdência alargando-as a um leque mais vasto de associados (FERREIRA; PEREIRA, 2016).

A questão da Sede e do ambiente das Casas do Povo é outro ponto que espelha uma realidade pouco satisfatória em relação ao ideal corporativo. A sede como espaço físico não é chamativa para os sócios. Considerados por muitos como espaços reduzidos e com poucas condições, mobiliário escasso, refletem as realidades de cada localidade, e da situação financeira de cada organismo. Até porque muitas Casas do Povo não têm condições financeiras para a construção de um edifício próprio, consignando-se ao que a freguesia dispõe como opção. É então compreensível que a frequência a estes organismos não seja tão afluente como seria espectado, se nem o próprio edifício reúne condições. A isto acresce a visão negativa que alguns associados depositam neste espaço, visto que as regalias do pagamento de quotas são escassas para o valor mensal que lhes é cobrado. E este panorama reflete-se nos inquéritos, pois os itens correspondentes à previdência e assistência, às atividades, ação cultural, ou mesmo ao fomento local, são os menos respondidos. Já que pouco ou nada estava realizado, sequer pensado.

Embora este seja o panorama apontado por algumas destas Casas do Povo é bom referir que o Distrito de Braga também apresenta Casas de exemplo, e que mereceram, de 
acordo com a Junta Central, a entrada para o "Quadro de Honra", como é o caso da Casa do Povo de Lousado. O Mensário das Casas do Povo, no ano de 1949, aponta-a como um dos melhores organismos em todo o país, pelas seguintes razões:

"além do excelente aspecto exterior da sua sede social, possui: um grande e bem apetrechado salão recreativo, com excelente frequência de sócios (...), dotado de dois bilhares, uma telefonia, uma mesa de ping-pong, e outros jogos lícitos; um gabinete da direção que está a ser convenientemente mobilado em estilo regional; um consultório médico; um posto de correio; uma ampla sala de espetáculos, com o respectivo palco (...) e até uma cabina para projeções cinematográficas; (...) reorganiza, actualmente, o seu Rancho Folclórico e o seu Grupo Cénico"²0.

A deficiência de respostas aos diferentes capítulos do presente questionário é, por algumas Casas do Povo explicada no último capítulo deste inquérito. Apresentam-se opiniões variadas, umas justificadas por motivos de suspensão que percorreu o ano anterior ao inquérito, outras pelo reduzido número de subsídios, de que é exemplo a seguinte resposta:

"Talvez cause estranheza a pobreza de iniciativas desta Casa do Povo e a deficiência deste inquérito parecendo à primeira vista que se torna inútil semelhante organização nesta área. A causa porém da fraca atividade desta Casa do Povo está na insuficiência de subsídios que lhe têm sido concedidos, pois nos três anos em que ela funciona só totalizaram cinco mil escudos. Há melhor vontade na atual direção de lançar esta Casa do Povo em iniciativas que a tornem querida do trabalhador rural o que necessitamos é de dinheiro. Sem isso a nossa ação torna-se imprópria e insustentável."21

Mas é também neste último ponto que se vislumbram algumas das sugestões por parte das Casas do Povo para a sua melhoria: solicitação de subsídios; sugestão de cobrança aos sócios contribuintes pelo meio do Estado; ou mesmo a renumeração dos empregados das Casas do Povo.

\footnotetext{
${ }^{20}$ TEIGUEIROS, Miguel. Quadro de Honra. Casa do Povo de Lousado. Mensário das Casas do Povo. Ano III, N. ${ }^{\circ}$ 36, Lisboa: Junta Central das Casas do Povo, Junho, 1949.

${ }^{21}$ Resposta da Casa do Povo de Serzedo ao Inquérito de 1947 da Junta Central das Casas do Povo.
} 


\section{CONCLUSÃO}

Aquando deste inquérito havia muito ainda para fazer nestes organismos, as dificuldades eram visíveis e diferenciadas. As Casas do Povo apresentam falhas e constrangimentos em comum, e refletem a sua própria edificação: rápida mas com pouca substância. Há a necessidade de se constituírem Casas do Povo cobrindo uma maior área rural, mas a sobrevivência das mesmas está aquém do espectado, o que denota que o Estado desconhecia as diferentes realidades. E mesmo apesar de deter o controlo destes organismos, vigiando-os periodicamente através das inspeções, é moroso na solução dos problemas, disso nos dão conta estes Inquéritos da Junta Central das Casas do Povo. As respostas, em alguns casos, são um pedido para esclarecimento de dúvidas, um reforço do trabalho que tem vindo a ser feito, e também, a justificação para incumprimentos ou faltas de registo.

É pertinente perceber com mais detalhe, e o progresso das investigações o permitirão, se os órgãos diretivos têm uma clara influência na gestão destes organismos, e ao mesmo tempo perceber se há disparidades na gestão interna das Casas do Povo, olhando-as ao distrito. Os problemas detetados nestes organismos são diversos, mas também eles comuns sede, quotas, previdência e assistência, gestão financeira, entre outros - e que traduzem os seus constrangimentos.

A Junta Central das Casas do Povo é constituída como órgão de orientação e coordenação destes organismos, face às inúmeras dificuldades e dúvidas que são dirigidas e solicitadas ao Delegado do Instituto Nacional do Trabalho e Previdência. A própria legislação (Decreto-Lei $\mathrm{n}^{\circ} .34373$, de 10 de janeiro de 1945) refere que a sua atividade deve ser exercida em ligação com o Instituto Nacional do Trabalho e Previdência, passando todas as orientações, documentos e sugestões pela delegação de cada distrito. Se por um lado, a Junta Central é criada como apoio das Casas do Povo, é também ela mais um mecanismo de controlo por parte do Estado. E nesse caminho seguem as Federações das Casas do Povo (Decreto-Lei n. ${ }^{\circ}$ 41286, de 23 de setembro de 1957), mais com funções ligadas à previdência social, e à representação dos trabalhadores rurais.

\section{FONTES IMPRESSAS}

Mensário das Casas do Povo

Oficina do Historiador, Porto Alegre, EDIPUCRS, v. 9, n. 2, jul./dez. 2016 
Boletim do Instituto Nacional do Trabalho e Previdência anos

Inquérito às Casas do Povo, 1947 - Junta Central das Casas do Povo - Fundo das Casas do Povo - Arquivo do Centro Distrital de Braga da Segurança Social

\section{REFERÊNCIAS BIBLIOGRÁFICAS}

ALVES, Maria Manuela da Silva Fernandes. As Casas do Povo como instituições reveladoras da Mundividência do regime Salazarista. 1998. 171. Tese de Mestrado em História das Instituições e Cultura Moderna e Contemporânea. Instituto de Ciências Sociais, Universidade do Minho, Braga, 1998.

AMARAL, Diogo Freitas do. Corporativismo, Fascismo e Constituição. In: ROSAS, Fernando; GARRIDO, Álvaro (Coord.). Corporativismo, Fascismos, Estado Novo. Coimbra: Edições Almedina, 2012. p. 49-79.

ARAÚJO, César; FERREIRA, Silva; TEOTÓNIO, Gonçalves. Colecção de Legislação Corporativa do Trabalho e Previdência. Lisboa: S.ed., 1969.

BARREIRA, Óscar Rodríguez; TÁBOAS, Daniel Lanero. Juventud y Campesinado en las falanges rurales: España, 1939-50. História Agrária, n. ${ }^{\circ}$ 62, p. 177-216, 2014.

BARROS, Afonso. Do latifundismo à reforma agrária. O caso de uma freguesia do Baixo Alentejo. Lisboa: CEEA; Instituto Gulbenkian de Ciência, 1986.

FERNÁNDEZ, David Soto; PRIETO, Lourenzo Fernández. Política Florestal e conflictividade nas terras comunais de Galicia durante o Franquismo (1939-1975). In: FREIRE, Dulce; FONSECA, Inês; GODINHO, Paula (Coord.). Mundo Rural. Transformação e Resistência na Península Ibérica (Século XX). Lisboa: Edições Colibri, 2004. p. 225-249.

FERREIRA, Fátima Moura; PEREIRA, Natália M. Magalhães. As dinâmicas internas das Casas do Povo sob o olhar das inspeções (anos 40 a início dos anos 70). Comunicação apresentada no Congresso Internacional - Espaços Corporativos e Escalas Urbanas no Século XX - Organismos Primários, Estruturas Administrativas e Ordem Estatal. Braga: Universidade do Minho, abr-2015. (No prelo)

FONSECA, Inês. A bem da Nação! Modernização e resistência em meio rural durante o Estado Novo. In: FREIRE, Dulce; FONSECA, Inês; GODINHO, Paula (Coord.). Mundo Rural. Transformação e Resistência na Península Ibérica (Século XX). Lisboa: Edições Colibri, 2004. p. 71-105.

FREIRE, Dulce. O Estado Corporativo em acção: sociedade rural e construção da rede de Casas do Povo. In: ROSAS, Fernando; GARRIDO, Álvaro (Coord.). Corporativismo, Fascismos, Estado Novo. Coimbra: Edições Almedina, 2012. p. 273-302.

FREIRE, Dulce; FERREIRA, Nuno Estevão; RODRIGUES, Ana Margarida. Corporativismo e Estado Novo. Contributo para um roteiro de Arquivos das Instituições Corporativas (19331974). Estudos \& Relatórios ICS, ER1-2014. Disponível em: 
http://www.ics.ul.pt/publicacoes/workingpapers/wp2014/er2014_1.pdf.

Dezembro, 2014.

GAGLIARDI, Alessio. Il corporativismo fascista. Bari: Gius, Laterza \& Figli, 2010.

GARRIDO, Álvaro. O Estado Novo e as Pescas. A recriação historicista de uma "Tradição Marítima Nacional". In: TORGAL, Luís Reis; PAULO, Heloísa (Coord.). Estados autoritários e totalitários e suas representações. Coimbra: Imprensa da Universidade de Coimbra, 2008. p. 99-118.

GARRIDO, Álvaro. A terra e o mar não se sindicalizam! As casas dos pescadores no sistema corporativo do Estado Novo português (1933-1968). In: PASETTI, Matteo (Eds.). Tra due crisi: Urbanizzazione, mutamenti sociali e cultura di massa tra gli anni Trenta e gli anni Settanta. Bolonha: Archetipo Libri, 2012. p. 87-110.

GARRIDO, Álvaro. Uma história da Economia Social. Lisboa: Tinta da China, 2016.

LUCENA, Manuel de. A evolução do sistema corporativo português. Vol. I. O Salazarismo. Lisboa: Perspectivas \& Realidades, 1976a.

LUCENA, Manuel de. A evolução do sistema corporativo português. Vol. II. O Marcelismo. Lisboa: Perspectivas \& Realidades, $1976 b$.

LUCENA, Manuel de. Casas do Povo. In: BARRETO, A; MÓNICA, M. Filomena (ed.). Dicionário de História de Portugal. Lisboa: Figueirinhas, 1999, Vol. III: Suplemento A/E.

LUCENA, Manuel de. Os lugar-tenentes de Salazar: Armindo Monteiro, Pedro Theotónio Pereira, Alberto Franco Nogueira, José Gonçalo Correia de Oliveira, Adriano Moreira. Biografias. Lisboa: Alêtheia, 2015.

PATRIARCA, Fátima. A questão Social no Salazarismo. 1930-1947. Vol. I. Lisboa: Imprensa Nacional Casa da Moeda, 1995.

PEREIRA, Maria Eugénia Torres; CALADO, Carlos Alberto Domingues. Casas do Povo. Legislação Coordenada e Anotada. Despachos Normativos. Modelos Exemplos. Lisboa: Editorial Império, 1940.

PINTO, António Costa; MARTINHO, Francisco Palomanes (Org.). A vaga corporativa: corporativismo e ditaduras na Europa e na América Latina. Lisboa: Instituto de Ciências Sociais, 2016.

ROLLO, Fernanda. Erupção dos paradoxos. Desmandos da organização corporativa e reencontros do corporativismo no rescaldo da II Guerra. O inquérito à organização corporativa em 1947. In: ROSAS, Fernando; GARRIDO, Álvaro (Coord.). Corporativismo, Fascismos, Estado Novo. Coimbra: Edições Almedina, 2012. P. 189-225.

ROSAS, Fernando; GARRIDO, Álvaro (Coord.). Corporativismo, Fascismos, Estado Novo. Coimbra: Edições Almedina, 2012. 
ROSAS, Fernando. O corporativismo Enquanto Regime. In: ROSAS, Fernando; GARRIDO, Álvaro (Coord.). Corporativismo, Fascismos, Estado Novo. Coimbra: Edições Almedina, 2012. p. 17-47.

SERAPIGLIA, Daniele. La Via portuguese al corporativismo. Roma: Carocci, 2011.

TORRES, Jorge Filipe Mano da Silva. Os comerciantes e o Grémio do Comércio de Guimarães. Dinâmicas associativas, corporativas e comerciais (1939-1969). 2013. 167. Dissertação de Mestrado em História. Instituto de Ciências Sociais, Universidade do Minho, Braga, 2013.

VILLAVERDE, M. Cabo; TÀBOAS, Daniel Lanero. Associativismo agrario y transformaciones de la sociedad rural en España y Portugal: uma visión a largo prazo (18801975). In: TÀBOAS, Daniel Lanero; FREIRE, Dulce (ed.). Agricultura e innovación tecnológica en la Península Ibérica (1946-1986). Madrid: Ministerio de Medio Ambiente y Medio Rural y Marino, 2011.

WIARDA, Howard, J. O corporativismo em Portugal e no mundo moderno. In: GASPAR, Carlos; PATRIARCA, Fátima; MATOS, Luís Salgado de Matos (Org.). Estado, Regimes e Revoluções. Estudos em homenagem a Manuel Lucena. Lisboa: ICS. Imprensa de Ciências Sociais, 2012. p. 263-276.

ARTIGO ENVIADO EM: 17/11/.2016. ACEITO PARA PUBLICAÇÃO EM: 16/12/2016. 